\title{
Research on 5E Mode of Talent Cultivation for School-enterprise Cooperation Based on Double- Creative Education
}

\author{
Qinghui Guo \\ Shandong Xiehe University \\ Jinan, China
}

\begin{abstract}
The traditional research on school-enterprise cooperation has remained at the superficial level, without indepth and detailed research on the specific content of cooperation. It is not clear who should do it and what should be done, how to do it, as well as what the rights and responsibilities are, so there is no great guiding significance. On the basis of analyzing the problems existing in several common school-enterprise cooperation modes in China, this paper discusses the " $5 \mathrm{E}$ " mode of school-enterprise cooperation and puts forward five important nodes of talent training quality. That is, Entrance, Education, Examination, Experiment, Employment. School-enterprise cooperation object is standardized and the main areas of schoolenterprise cooperation are clarified. Therefore, the schoolenterprise cooperation is standardized from the current general talk to the specific content, which reflects the requirements of total-quality management of applied talents training.
\end{abstract}

Keywords-school-enterprise cooperation; applied talents; the whole process; $5 E$ mode; task list

\section{THE CONCEPT OF SCHOOL-ENTERPRISE COOPERATION}

In the process of training applied talents in colleges and universities, the role of enterprises cannot be ignored. First of all, enterprises are the best demanders of talents. In the $21 \mathrm{st}$ century, the essence of enterprise competition is basically the competition of talents and intelligence. The final output of the talents cultivated by the school is the enterprise, while the enterprise is the recipient of the talent, and the school and the enterprise are interdependent and mutually reinforcing. Secondly, there is a lag in the training of talents in schools. This lag is not only reflected in the mastery of talent information in the market and the judgment of the situation of talent demand, but also in the training of theoretical knowledge content, talent ability and quality structure in classroom teaching. However, enterprises know best about the demand for talents in the market and also know best the knowledge and ability structure of the required talents. Therefore, in the process of training applied talents in schools, we should fully consider the role of enterprises in the cultivation process, make full use of the various effective resources of enterprises, and cooperate with schools and enterprises to cultivate the talents needed by the market.

School-enterprise cooperation mode began in the 19th

This paper is the 2019 annual topic of the "13th Five-Year Plan" for the national business education and scientific research: Based on the dualcreation education, the tourism management professional cooperation personnel training 5E model research (Number: SKJYKT-1919) phased results. century abroad. After more than 100 years of research and discussion, it has entered a relatively mature stage of development. The so-called school-enterprise cooperation refers to the needs of the enterprises in the market, and the school combines the needs of enterprises in the process of training talents. Make full use of the resources of both school and enterprise to realize the organic combination of teaching in school and practice outside school. Both school and enterprise should participate in and jointly cultivate the training mode of application-oriented talents with comprehensive quality and comprehensive ability and certain employment competitiveness that enterprises need.

\section{COMMON PATTERNS OF SCHOOL-ENTERPRISE COOPERATION}

In foreign countries, currently influential schoolenterprise cooperation models include the "cooperative education" in the United States, the "dual system" in Germany, the "work-study alternation system" in Britain, the "TAFE" in Australia, the CO-OP paid internship in Canada, etc. These models also have a high reference for the application of the domestic school-enterprise cooperation model.

In the 1960s, China began to introduce a schoolenterprise cooperation model. After decades of research and development, a systematic cooperation model has been initially formed. At present, there are more than 20 cooperation modes in use in China, but the common and effective cooperation modes are "work-study combination", "order form", "N+1", "1+1+1+n" and so on.

\section{A. "Work-study combination" mode}

The so-called "work-study combination" refers to a schoolenterprise cooperation mode that organically combines students' theoretical study in school with their job practice in enterprises to cultivate talents, usually implemented in the form of "study-work-study". This model breaks the traditional teaching plan. It arranges students to study the theoretical knowledge of the school in one semester, and then arranges the students to go to the enterprise for a semester of internship, apply the theoretical knowledge learned to practice, and finally return to school. Consolidate and improve theoretical knowledge. This form of part-time work and part-time reading 
can enable students to integrate theory with practice, improve their professional skills and improve their practical operation ability. However, the lack of this model is that the theoretical knowledge learning in the student school and the internship in the enterprise are cross-cutting, which is easy to disrupt the student's knowledge system and make the organization of the professional curriculum more difficult.

\section{B. "Order form" model}

"Order-based" is a mode in which both the school and the enterprise sign a talent training agreement, the school and the enterprise jointly formulate a talent training plan, the school trains talents according to the enterprise's demand standard and quantity for talents, and the enterprise provides internship jobs. Most universities in Shandong Province adopt this model. In the process of school-enterprise co-cultivation of talents, enterprises not only participate in the formulation of personnel training programs, but also participate in the teaching tasks of some courses.

\section{C. "N+1" model}

"N+1" is a kind of school-enterprise cooperation mode which is widely used at present. Generally speaking, " $3+1$ " mode is adopted at undergraduate level and " $2+1$ " mode is adopted at specialty level. This training mode divides the teaching process into two stages. The first stage is that students in the previous $\mathrm{N}$ years receive systematic professional and theoretical knowledge education in school, and the second stage is that students go to school-enterprise cooperation enterprises for on-the-job internship and graduation internship in the remaining year. In this way, students can master the professional theoretical knowledge well, and master the professional practical skills required for practical work. In the process of implementing this mode, there may be a situation that the " $n$ " and "1" are disconnected due to the low cooperation between school and enterprise, which makes the theoretical study and practical operation unable to be effectively connected.

\section{D. " $1+1+1+n "$ tutorial system}

The so-called " $1+1+1+n "$ tutorial system is a schoolenterprise cooperation mode in which students are divided into groups, and the studies of $\mathrm{n}$ students in the group are specifically responsible for by three tutors with clear division of labor. Teachers are professional teachers, industry instructors and counselors. Professional teachers are responsible for the teaching of $\mathrm{N}$ students' professional theoretical knowledge. Industry instructors are responsible for the examination of students' professional qualification certificates, practice and employment guidance, while counselors are responsible for solving students' psychological and life problems.

\section{PROBLEMS EXISTING IN SCHOOL-ENTERPRISE COOPERATION}

\section{A. The integration of higher education and industrial development is insufficient, and the synergy of resources is not obvious}

The reason for school-enterprise cooperation is to integrate the effective resources of both sides and realize the sharing of resources through complementary advantages. However, as far as the development of domestic school-enterprise cooperation is concerned, the relevant domestic laws and regulations and the degree of teaching reform in universities cannot meet the development needs of the integration of production and education. Coupled with the lack of information sharing mechanism and guarantee system, college education and Insufficient integration of industrial development, to a certain extent, it has affected the development effect of schoolenterprise cooperation and cooperation in educating people, resulting in some undesirable situations when the two sides of the school and enterprise integrate advantageous resources, such as: repeated purchase of some equipment and low utilization rate; It can not give full play to the role of the training base inside and outside the school, but as a place for students' in-school and out-of-school practice, the function utilization is relatively single, and there is no effective integration of the teachers of both schools and enterprises.

\section{B. The interaction between the school and the enterprise is not active, and the connotation of cooperation is not profound}

Under the condition of market economy, the fundamental goal of enterprises is to obtain more economic benefits, while colleges and universities, as the training base of talents, pay more attention to the cultivation of students' theoretical knowledge and practical ability. The inconsistency between the purpose of talent training and the development goals of the company, coupled with the fact that the company believes that it has paid more and gained less in the process of cooperation, resulting in poor interaction between the school and the enterprise in the process of cooperation. Colleges and universities are not pushing hard enough, and the enthusiasm of enterprises to participate is not high, which makes schoolenterprise cooperation too formal. Emphasizing superficial things such as venue, equipment and teaching hours, the cooperation degree of the connotation construction of textbook construction, employment quality and improvement of teachers' ability is not deep, and school-enterprise cooperation finally becomes a mere formality.

\section{The consciousness of teaching reform is not active and the concept of talent cultivation is not harmonious}

In the process of school-enterprise cooperation, there is often a situation in which enterprises pay more attention to students' practical ability. Therefore, they often hope that schools can pay attention to practical teaching, and even hope that schools can arrange more time for students to go to enterprises for internship training; However, some teachers in schools have outdated teaching reform concepts and can not keep pace with the times. They are still accustomed to the 
traditional teaching mode of theoretical knowledge, emphasizing theory and neglecting practice. Inconsistency of training concepts and lack of communication and communication, the students finally trained can neither achieve the goal of training applied talents nor meet the demand standard of enterprises for talents, which affects the in-depth cooperation and resource sharing of school-enterprise cooperation.

\section{RESEARCH ON "5E" MODE OF SCHOOL-ENTERPRISE COOPERATION}

We will establish a teaching organization and quality assurance system for full cooperation between schools and enterprises, strengthen the monitoring of teaching quality, and ensure the realization of the innovative mode of personnel training. According to the principle of total quality management, starting from the five key points that affect the quality of students' training, the whole process of schoolenterprise cooperation personnel training mode focusing on "5E" from "import" to "export" is implemented. "5E" means: Entrance enrollment, Education training, Examination assessment, Experiment internship, Employment employment. A 5E-based school-enterprise cooperation system model $\mathrm{Y}=\mathrm{F}(\mathrm{E} 1, \mathrm{E} 2, \mathrm{E} 3, \mathrm{E} 4, \mathrm{E} 5)(\mathrm{Y}$ is the training quality) is constructed, and a task list study is carried out around five key quality control nodes in tourism specialty.

\section{A. Entrance}

School-enterprise joint enrollment, enterprises to provide students with part of the tuition fees or scholarships; Schools, students and enterprises sign training agreements. Focus on the existing institutional and institutional barriers affecting the joint enrollment of schools and enterprises; the problems and countermeasures in the implementation of order-based talent training; the tripartite agreements and contents of students, enterprises and schools; The feasibility study of the interview, the interview content and the weight of the results, etc.

\section{B. Education}

According to the connotation of applied tourism professionals and their post competence requirements, both schools and enterprises sort out the basic requirements for talents of different types of tourism enterprises, such as travel agencies and hotels. Based on the experience of foreign countries, formulate job requirements standards, and jointly develop tourism talent training programs and corresponding curriculum systems based on job standards and competency requirements; To send teachers to each other so as to realize the common cultivation of talents. Standardize the procedures and systems for school-enterprise cooperation in developing personnel training programs. Both schools and enterprises shall jointly set up a teaching supervision organization, formulate its articles of association, and sort out the courses served by enterprise experts and the courses that students practice while studying in enterprises. On the basis of the cooperation between the school and the enterprise, list different projects and corresponding tasks and responsibilities, and carry out comprehensive innovation reforms on the existing curriculum system, teaching content and class schedule.

\section{Examination}

Reform the current examination and assessment system and implement the system of school-enterprise cooperation to jointly evaluate the teaching quality. Enterprises focus on capability assessment and implement open-book examination. The school focuses on the assessment of basic knowledge and implements a closed book system. A list of courses and a list of liability guarantees, which are mainly based on enterprises and schools, are listed.

\section{Experiment}

The list of contents, quantity and quality requirements of students' internships inside and outside the school; Internship program; List of double tutorial systems for internship and probation.

\section{E. Employment}

Students and cooperative enterprises have two-way choices to determine employment. Students fulfill the order agreement; The employer shall give feedback on the training quality of the students to further improve the training quality. Establish an employment feedback mechanism and revise the process of talent training model.

\section{THE SIGNIFICANCE OF IMPLEMENTING "5E" MODEL OF SCHOOL-ENTERPRISE COOPERATION}

\section{A. Promote the development of students' comprehensive professional quality}

School-enterprise cooperative teaching can not only connect theory with practice, but also make the teaching content more targeted, and can help them understand job information and help them in their future employment choices. All these are of great help to the cultivation of students' comprehensive professional quality.

\section{B. Promote the development of school teachers and enterprise personnel themselves}

School-enterprise cooperation teaching is a challenge to both full-time teachers in schools and part-time teachers in enterprises. The full-time teachers of the school need to break the "safe state" of repeating the same teaching day after day, re-examine the whole course teaching and even the whole professional curriculum, and incorporate the latest enterprise needs into the design of the course teaching. On the other hand, part-time teachers in enterprises need to change their identities and learn to communicate effectively with students, so that they not only know their professional knowledge well, but also can be accepted and mastered quickly by others. These can promote the comprehensive development of the school's fulltime teachers and part-time teachers.

\section{Strengthening the links and cooperation between schools and enterprises}

The cooperation between schools and enterprises exists in many aspects, such as order training, mutual employment, technical services, cooperative development, etc. Among them, school teachers and enterprise personnel pay more attention to 
cooperation in research and development of specific projects. However, according to the survey results, it can be seen that a considerable number of school teachers have the ability to cooperate, but have no opportunity to contact with enterprises. Some companies also have high enthusiasm for cooperation, but they have not been able to contact the appropriate partners. The biggest difference between school-enterprise cooperation teaching and other aspects of school-enterprise cooperation is that the main body of cooperation is specific school teachers and enterprise employees, rather than some large-scale cooperation at the school and enterprise level. In addition, its coverage is more extensive and can basically benefit every professional teacher. Therefore, the school-enterprise cooperation teaching of each course is like building small but steady bridges between schools and enterprises. If we persist in the long-term development, we can effectively promote the implementation of other aspects of cooperation between schools and enterprises.

\section{Optimize professional setting and development of talent training programs}

The core of school-enterprise cooperation teaching is the cultivation of talents. Through cooperation teaching, schools cultivate talents that meet the job requirements of enterprises, and enterprises can give priority to obtaining talents that meet their own needs. Therefore, the school-enterprise cooperation teaching is not only at the teaching level, it also includes the cooperation and screening of the course content, the cooperation and formulation of a professional talent training program, and even the professional settings of the entire school and department.

It is conducive to the improvement of teaching effect, and is more conducive to optimizing the setting of the entire profession and formulating a talent training plan that meets the actual needs of the post.

\section{CONCLUSION}

The ultimate goal of school-enterprise cooperation is to promote the improvement of students' comprehensive quality. Schools and enterprises play the role of guiding and providing help and resources, and emphasize the joint participation and joint training of both schools and enterprises.

Through the implementation of the full-scale cooperation between the school and enterprise in the 5E mode, the schoolenterprise cooperation in the whole process of talent cultivation can be realized, reflecting the requirements of the comprehensive quality management of the application-oriented personnel training.

\section{REFERENCES}

[1] Liu Xin et al. Comparative Analysis of School-enterprise Cooperation Models at Home and Abroad [J]. modern business trade industry, 2018(10):67-69. (In Chinese)

[2] Liu Fan, Cai Kedi. Analysis of School-enterprise Cooperation Model from the Perspective of Innovative Ideas [J]. Journal of bohai university, 2018(2):133-137. (In Chinese)

[3] Tao Xia. School-enterprise cooperation mode, system comparison and experience reference of vocational education in Germany and Germany [J]. Education and occupation, 2018 (8): 19-25. (In Chinese)

[4] Zhang Kun. Research on School-enterprise Cooperation Model of Financial Management Major in Colleges and Universities-Based on School-enterprise Cooperation Practice in Shandong Province [J]. Journal of xinxiang university, 2018(1):74-76. (In Chinese)

[5] Tong Gui, Zheng Xin. Innovative mode of applied talents cultivation from "school-enterprise cooperation" to "school-enterprise integration" [J]. Journal of Nanjing Institute of Engineering (Social Science Edition), 2018.18 (1): 76-80. (In Chinese) 